\title{
Prostate Cancer and Bone Marrow Involvement
}

\author{
Prostat Kanseri ve Kemik iliği Tutulumu \\ (D) Havva Yeşil Çınkır¹, (D) Zehra Bozdă̆2 \\ ${ }^{2}$ Gaziantep University Faculty of Medicine, Department of Pathology, Gaziantep, Turkey

\begin{abstract}
Introduction: Bone marrow involvement (BoMI) may be common during the tumour's lifespan or, sometimes, it may be the first sign of manifestation of a disease. Prostate cancer at an extensive stage has osteoblastic bone metastasis. The purpose of this study is to explore the results of prostate cancer with BoMl that is diagnosed by bone marrow biopsy.
\end{abstract} \\ Methods: We retrospectively evaluated 55 patients with BoMI \\ of solid tumours and 8 patients with histopathologically \\ proven BoMI of prostate cancer. The overall survival (OS) was \\ demonstrated by Kaplan-Meier analysis, and the curves were \\ compared by the log-rank test. \\ Results: The median age of patients was 67.5 years (range: \\ 46-83 years). Bone was the most common site of metastasis, \\ except BoMI ( $n=8,100 \%)$. At the time of diagnosis of BoMI, \\ the most abnormal haematological findings were anaemia \\ (87.5\%) and thrombocytopenia (87.5\%), followed by leucopenia \\ (37.5\%). The median time of BoMl was 16.8 months (range: \\ 0 -57.8). The median and mean OS after the diagnosis of \\ BoMI were 38 days [95\% confidence interval (Cl); 0-175.2] \\ and 143 days $(95 \% \mathrm{Cl} ; 27.7-259.9)$, respectively. According to \\ the treatment status after BoMI, median OS were 215 days for \\ patients who underwent oncologic treatment and 21 days in \\ patients followed up with best supportive care (BSC) $(p=0.014)$. \\ Conclusion: BoMI in prostate cancer and other solid tumours \\ remain a dismal situation. According to survival difference \\ between the patients who received treatment and BSC after \\ BoMI diagnosis, patients who are eligible for oncologic \\ treatment should be encouraged for continuing the treatment. \\ Keywords: Bone marrow involvement, prostate cancer, survival
}

${ }^{1}$ Gaziantep University Faculty of Medicine, Department of Medical Oncology, Gaziantep, Turkey

\section{öZ}

Amaç: Kemik iliği tutulumu (KelT) tümörün seyri boyunca yaygın olabilir veya bazen hastalık belirtisinin ilk belirtisi olabilir. Yaygın evre prostat kanseri genellikle osteoblastik kemik metastazına sahiptir. Bu çalıșmada kemik iliği biyopsisi ile tanı konan KelT prostat kanseri sonuçlarını araștırmayı amaçladık.

Yöntemler: KeIT olan solid tümörlü 55 hasta vardı ve histopatolojik olarak kanıtlanmış prostat kanseri tanısı olan toplam 8 hasta retrospektif olarak incelendi. Genel sağkalım (GSK), Kaplan-Meier analizi ile gösterildi ve eğriler log-rank testi ile karșılaștırıldı.

Bulgular: Hastaların ortanca yașı 67.5 idi (46-83). Kemik, KelT dișında en sık metastaz bölgesiydi ( $n=8, \% 100)$. KelT tanısı sırasında anormal hematolojik bulgular anemi (\% 87.5) ve trombositopeni (\%87.5), ardından lökopeni (\%37.5) idi. Ortalama KeIT süresi 16.8 aydı (0-57.8). KelT tanısı sonrası ortalama ve ortanca GSK sırasıyla 38 gün (\%95 GA; 0-175.2) ve 143 gün (\% 95 GA; 27.7-259.9) olarak saptandı. KelT sonrası tedavi durumuna göre ortanca GSK, onkolojik tedavi uygulanan hastalar için 215 gün ve palyatif destek tedavisi ile takip edilen hastalarda 21 gün idi ( $p=0.014)$.

Sonuç: KeIT, prostat kanseri ve diğer solid tümörlerde kasvetli olmaya devam etmektedir. KeIT tanısı sonrası tedavi grupları arasındaki sağkalım farkına göre, uygun hastalar onkolojik tedavi için teşvik edilmelidir.

Anahtar Kelimeler: Kemik iliği tutulumu, prostat kanseri, sağkalım

\section{Introduction}

Bone marrow (BoM) is defined as the metastatic focus (soft tissue) in which the cancer cells secretly spread before making extensive metastasis in solid tumours (1). Bone marrow involvement (BoMI) is suspected in the presence of clinical findings such as anaemia, thrombocytopenia, leucopenia, bicytopenia or pancytopenia in patients with solid tumours. In some cases, BoMl can be diagnosed without any change in haematological parameters (2). BoMI may be common during the tumour's lifespan or, sometimes, it may be the first sign of manifestation of a disease (3). Prostate cancer at an extensive stage usually has osteoblastic bone metastasis. After prostate cancer metastasises to the bone, a vicious cycle of turnover occurs between the bone surface and the BoM stroma (4). The purpose of this study is to explore the results

Cite this article as/Atıf: Yeşil Çınkır H, Bozdağ Z. Prostate Cancer and Bone Marrow Involvement. İstanbul Med J 2020; 21(3): 196-9.

(C) Copyright 2020 by the University of Health Sciences Turkey, Istanbul Training and Research Hospital/Istanbul Medical Journal published by Galenos Publishing House

(C) Telif Hakkı 2020 Sağıı Bilimleri Üniversitesi Istanbul Ĕgitim ve Araştırma Hastanesi/Istanbul Tıp Dergisi, Galenos Yayınevi tarafından basılmıștır. 
of prostate cancer with BoMI that is diagnosed by diagnosed by BoM biopsy.

\section{Methods}

\section{Study Design}

We retrospectively evaluated 55 patients with BoMI of solid tumours and 8 patients with histopathologically proven prostate cancer with BoMI at the Gaziantep University Faculty of Medicine between 2012 and 2019.

We obtained the clinical characteristics of patients as well as their age, date of diagnosis of prostate cancer and BoMI, Gleason score, sites of metastases, complete blood counts, biochemical parameters, treatment history, date of death or last follow-up from the hospital records. Anaemia was defined as the condition with haemoglobin value $\leq 12 \mathrm{gr} /$ $\mathrm{dL}$, thrombocytopenia was defined as the condition with platelet counts below $150.000 / \mathrm{mm}^{3}$, and leucopenia was defined as white blood cells count lower than $3500 / \mathrm{mm}^{3}$.

The ethics committee of the Gaziantep University (Decision no: 2019/304, date: 28.08.2019) approved this study's protocol. Written and informed consent was obtained from the patients before conducting procedures.

\section{Statistical Analyses}

In the analysis of demographic variables, we calculated the frequency and percentage distribution values. The overall survival (OS) was defined as the time interval between the diagnosis of BoMI and the death or last follow-up visit. We demonstrated OS by Kaplan-Meier analysis, and compared the curves by the log-rank test. Additionally, we performed statistical analysis with SPSS 22.0 software (SPSS, Chicago, IL, USA).

\section{Results}

Table 1 presents a detailed description of the demographic and clinical characteristics of patients. The median age of patients was 67.5 years (range: $46-83$ years). The clinical manifestations at the time of diagnosis of BoMl were fatigue, bone pain, fever and infection. However, one patient did not have any symptoms. All the eight patients had a histopathology of adenocarcinoma. Bone was the most common site of metastasis, except BoMI ( $\mathrm{n}=8,100 \%)$. Lymph node (62.5\%), lung (12.5\%) and liver (12.5\%) were some other sites with metastasis. At the time of diagnosis of BoMI, the most abnormal haematological findings were anaemia (87.5\%) and thrombocytopenia (87.5\%), followed by leucopenia (37.5\%). Pancytopenia was present in $37.5 \%$ of the patients, and $37.5 \%$ patients had bicytopenia. The evaluation of biochemistry finding revealed that alkaline phosphatase levels were high in seven patients, and all of patients had high lactate dehydrogenase and prostate specific antigen and none of them had hypercalcaemia (Table 2).

Two patients had BoMI during the first diagnosis of prostate cancer. After the diagnosis of BoMI, three patients received treatment (hormone therapy, chemotherapy) and five patients were followed up with best supportive care (BSC).

Table 1. Demographic and clinical characteristics of prostate cancer with bone marrow involvement

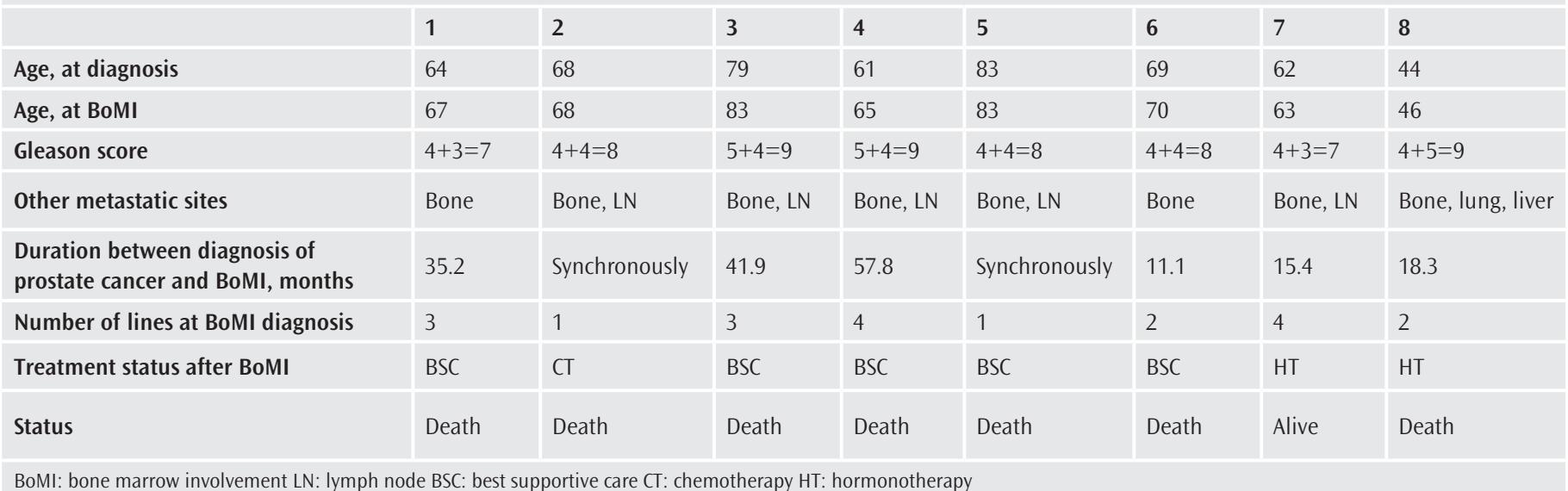

Table 2. Haematologic and biochemical changes of the bone marrow involvement with prostate cancer

\begin{tabular}{|c|c|c|c|c|c|c|c|c|}
\hline & 1 & 2 & 3 & 4 & 5 & 6 & 7 & 8 \\
\hline Anaemia & + & + & + & + & + & - & + & + \\
\hline Leukopenia & + & - & + & + & - & - & - & - \\
\hline Thrombocytopenia & + & - & + & + & + & + & + & + \\
\hline ALP & 413 & 3259 & 457 & 649 & 466 & 100 & 333 & 1686 \\
\hline LDH & 1236 & 1291 & 560 & 303 & 879 & 200 & 380 & 459 \\
\hline Calcium & 8.9 & 7.2 & 8.5 & 8.1 & 8.1 & 8.9 & 8.9 & 8.3 \\
\hline PSA & 200 & 288 & 759 & 580 & 265 & 30 & 31 & 100 \\
\hline $\begin{array}{l}\text { ALP: alkaline phosphat } \\
\text { Normal range: } L D H: 12 \\
\text { Calcium: } 8.4-10.2 \mathrm{mg} / \mathrm{d}\end{array}$ & : prosta & antigen & & & & & & \\
\hline
\end{tabular}




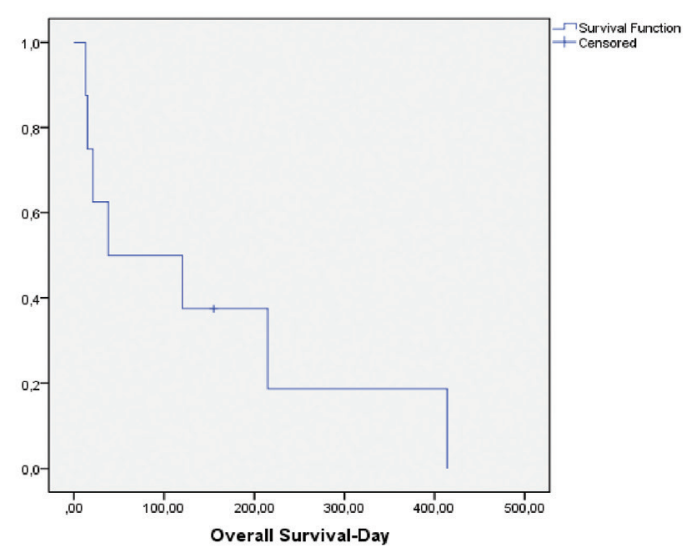

Figure 1. Median overall survival after the diagnosis of bone marrow involvement with prostate cancer [38 days $(95 \% \mathrm{Cl} ; 0-175.20)]$

$\mathrm{Cl}$ : confidence interval

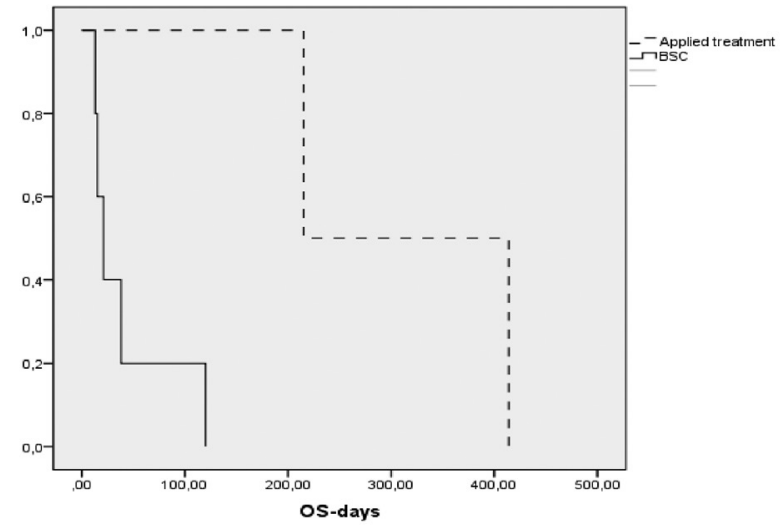

Figure 2. Median overall survival after the diagnosis of bone marrow involvement, according to the treatment options ( 21 days versus 215 days, in the favour of oncological treatment, $p=0.014$ )

At the time of analysis, the median follow-up time was 27.3 months (range: 0.9-61.8) and 7 patients died during the follow-up period. The median survival time for solid tumours after BoMI was 59 days [95\% confidence interval (Cl); 0-212]. The median survival time after the diagnosis of prostate cancer in these patients was 29.2 months $(95 \% \mathrm{Cl}$; 19.7-38.7). The median time of BoMl was 16.8 months (range: 0-57.8). The median and mean OS after the diagnosis of BoMI were 38 days (95\% $\mathrm{Cl}$; 0-175.2) and 143 days $(95 \% \mathrm{Cl} ; 27.7-259.9)$, respectively (Figure 1). According to the treatment status after BoMI, the median OS were 215 days for patients who underwent oncologic treatment and 21 days in patients followed up with BSC ( $p=0.014)$ (Figure 2).

The median OS of patients with thrombocytopenia was found as 38 days (95\% Cl; 0-81.6), while whereas the median OS of patients with normal thrombocyte value was 155 days (there was only one patient and he was alive). There was no statistically significance $(p=0.297)$. The median OS for patients with leucopenia and patient with normal values were 15 days (95\% Cl; 11.7-18.2) and 215 days (95\% Cl; 0-491), respectively, but there was no statistically significance $(p=0.073)$. There was no survival difference for anaemia $(p=0.353)$.

\section{Discussion}

The evaluation of BoM is a simple and cost-effective procedure, which is the best option for determining the BoMI of solid tumours (5). BoMI causes disruption in normal haematopoiesis, as well as the development of cytopenia and myelodysplastic anaemia (6). Haematologic parameters may differ in patients with BoMI. The presence of cytopenia prevents the patients from receiving an optimal dose of chemotherapy, and as a side effect of chemotherapy, the addition of cytopenia results in the worsening of disease prognosis. This study evaluated the clinical features of prostate cancer and BoMI at a single centre for over seven years. Most of the patients with prostate cancer are elderly, and BoM biopsy is crucial in these patients because they may accompany secondary malignancies or haematological diseases.

In the literature, the incidence of BoMI of prostate cancer has been reported at different rates (6.8-47.8\%) (7-10). Our study detected prostate cancer in 8 of 55 (14.5\%) adult patients with BoMI. The reasons for relatively less detection were: a high number of oncological treatment centres in our country; follow-up of the majority of patients diagnosed with prostate cancer in our country and region by the urology department; and the invasive procedure makes patients and physicians reluctant to perform the procedure, especially for end-stage patients who would not benefit from confirmation of BoMI.

The BoM microenvironment is the primary target for bone metastasis. Prostate cancer cells spread to bone, further mimicking haematopoietic cells, settling in the BoM and making life difficult for haematopoietic stem cells (11). Sometimes, BoMI can develop without bone metastasis. In our study, bone metastasis was present in all patients.

Similar to previous studies, the survival results of our study were dismal. In our study, the median survival time for solid tumours after BoMI was 59 days ( $95 \% \mathrm{Cl} ; 0-212)$, and the median OS after the diagnosis of BoMI for prostate cancer was 38 days $(95 \% \mathrm{Cl} ; 0-175.20)$. One study reported that the OS in solid tumours after BoMI was 28 days (12). For patients with prostate cancer, this period was reported as 18 days.

A study reported that the mean survival time was significantly different between groups receiving oncological treatment and BSC (121 days versus 11 days, $p<0.001$ ) (13). Our study found similar survival differences between the groups (215 days versus 21 days, $p=0.014$ ). BSC is an approach that should be applied during the treatment and follow-up of all patients with cancer. There is no optimal oncologic treatment approach for patients with BoMI; however, the survival time is prolonged with treatment. Therefore, supporting oncological therapy with BSC should be the main objective of treatment.

A study performed survival analysis according to the presence of thrombocytopenia in patients with BoMI (7). The median survival time were 1 month in patients with thrombocytopenia and 13 months in patients without thrombocytopenia. A similar result was obtained in another study ( 26 days versus 80 days, $p=0.042$ ). Haemorrhage and a lack of appropriate chemotherapy drugs have been the causes of the association between thrombocytopenia and survival (12). Our study's results found a significant difference between the two groups in the favour of the group without thrombocytopenia, but there was no 
statistical significance $(p=0.297)$. The presence of thrombocytopenia appeared to be an indicator of poor survival. Although there was no statistical significance, the presence of leucopenia was a poor prognostic indicator. Exposure of the patient to the infections and suboptimal treatment of the planned treatments were effective in the development of this condition.

\section{Conclusion}

BoMI in prostate cancer and other solid tumours remain a dismal situation. According to the survival difference between received treatment after BoMI diagnosis and BSC, patients who are eligible for oncologic treatment should be encouraged for continuing the treatment.

\section{Ethics}

Ethics Committee Approval: The study was approved by the ethics committee of Gaziantep University (Decision no: 2019/304, date: 28.08.2019).

Informed Consent: Written and informed consent was obtained from the patients before conducting procedures.

Peer-review: Externally peer-reviewed.

Authorship Contributions: Surgical and Medical Practices - H.Y.C.., Z.B.; Concept - H.Y.C.., Z.B.; Design - H.Y.C.., Z.B.; Data Collection or Processing - H.Y.C.., Z.B.; Analysis or Interpretation - H.Y.Ç.; Literature Search H.Y.Ç.; Writing - H.Y.C..

Conflict of Interest: No conflict of interest was declared by the authors.

Financial Disclosure: The authors declared that this study received no financial support.

\section{References}

1. Shiozawa Y, Eber MR, Berry JE, Taichman RS. Bone marrow as a metastatic niche for disseminated tumor cells from solid tumors. Bonekey Rep 2015; 4: 689 .
2. Singh G, Krause JR, Breitfeld V. Bone marrow examination: For metastatic tumor: Aspirate and biopsy. Cancer 1977; 40: 2317-21.

3. Wong KF, Chan JK, Ma SK. Solid tumour with initial presentation in the bone marrow -A clinicopathologic study of 25 adult cases. Hematol Oncol 1993; 11: $35-42$.

4. Miles FL, Kurtoglu S, Ahmer C, Soori M, Favate JS, Sikes RA. Transforming growth factor- $\beta$ signaling induced during prostate cancer cell death and neuroendocrine differentiation is mediated by bone marrow stromal cells. Prostate 2015; 75: 1802-13.

5. 5.Mehdi SR, Bhatt MLB. Metastasis of Solid Tumors in Bone Marrow: A Study from Northern India. Indian J Hematol Blood Transfus 2011; 27: 93-5.

6. Tasleem RA, Chowdhary ND, Kadri SM, Chowdhary QA. Metastasis of solid tumors in bone marrow: A study from Kashmir India. J Clin Pathol 2003; 56 : 803.

7. Kılıçkap S, Erman M, Dinçer M, Aksoy S, Harputluoğlu H, Yalçın Ş. Bone marrow metastasis of solid tumors: Clinicopathological evaluation of 73 cases. Turk J Cancer 2007; 37: 85-8.

8. Krishnan C, George TI, Arber DA. Bone Marrow Metastases: A Survey of nonhematologic metastases with immunohistochemical study of metastatic carcinomas. Appl Immunohistochem Mol Morphol 2007; 15: 1-7.

9. Hung Y-S, Chou W-C, Chen T-D, Chen TC, Wang P-N, Chang H, et al. Prognostic factors in adult patients with solid cancers and bone marrow metastases. Asian Pac J Cancer Prev 2014; 15: 61-7.

10. Mohanty SK, Dash S. Bone marrow metastasis in solid tumors. Indian J Pathol Microbiol 2003; 46: 613-6.

11. 11.Park SH, Keller ET, Shiozawa Y. Bone marrow microenvironment as a regulator and therapeutic target for prostate cancer bone metastasis. Calcif Tissue Int 2018; 102: 152-62.

12. Kucukzeybek BB, Calli AO, Kucukzeybek Y, Bener S, Dere Y, Dirican A, et al. The prognostic significance of bone marrow metastases: evaluation of 58 cases. Indian J Pathol Microbiol 2014; 57: 396-9.

13. Kwon JY, Yun J, Kim HJ, Kim KH, Kim SH, Lee SC, et al. Clinical outcome of gastric cancer patients with bone marrow metastases. Cancer Res Treat 2011; 43: 244-9. 